Article

\title{
Crustal Strain and Stress Fields in Egypt from Geodetic and Seismological Data
}

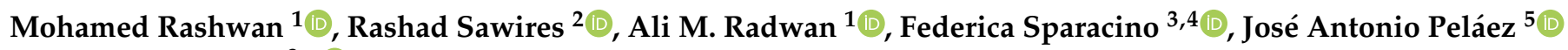 \\ and Mimmo Palano ${ }^{3, *}$ (i) \\ 1 National Research Institute of Astronomy and Geophysics (NRIAG), 11421 Helwan, Cairo, Egypt; \\ mohamed.rashwan@nriag.sci.eg (M.R.); ali.radwan@nriag.sci.eg (A.M.R.) \\ 2 Department of Geology, Faculty of Science, Assiut University, 71516 Assiut, Egypt; \\ rashad.sawires@aun.edu.eg \\ 3 Istituto Nazionale di Geofisica e Vulcanologia, Sezione di Catania - Osservatorio Etneo, I-95125 Catania, Italy; \\ federica.sparacino@ingv.it \\ 4 Dipartimento di Scienze Biologiche, Geologiche e Ambientali, Università degli Studi di Catania, \\ I-95129 Catania, Italy \\ 5 Department of Physics, University of Jaén, 23071 Jaén, Spain; japelaez@ujaen.es \\ * Correspondence: mimmo.palano@ingv.it
}

Citation: Rashwan, M.; Sawires, R.; Radwan, A.M.; Sparacino, F;

Peláez, J.A.; Palano, M. Crustal Strain and Stress Fields in Egypt from Geodetic and Seismological Data. Remote Sens. 2021, 13, 1398.

https://doi.org/10.3390/rs13071398

Academic Editor: Tomaž Podobnikar

Received: 26 February 2021

Accepted: 31 March 2021

Published: 5 April 2021

Publisher's Note: MDPI stays neutral with regard to jurisdictional claims in published maps and institutional affiliations.

Copyright: (c) 2021 by the authors. Licensee MDPI, Basel, Switzerland. This article is an open access article distributed under the terms and conditions of the Creative Commons Attribution (CC BY) license (https:/ / creativecommons.org/licenses/by/ $4.0 /)$.

\begin{abstract}
The comparison between crustal stress and surface strain azimuthal patterns has provided new insights into several complex tectonic settings worldwide. Here, we performed such a comparison for Egypt taking into account updated datasets of seismological and geodetic observations. In north-eastern Egypt, the stress field shows a fan-shaped azimuthal pattern with a WNW-ESE orientation on the Cairo region, which progressively rotated to NW-SE along the Gulf of Aqaba. The stress field shows a prevailing normal faulting regime, however, along the Sinai/Arabia plate boundary it coexists with a strike-slip faulting one $\left(\sigma_{1} \cong \sigma_{2}>\sigma_{3}\right)$, while on the Gulf of Suez, it is characterized by crustal extension occurring on near-orthogonal directions $\left(\sigma_{1}>\sigma_{2} \cong \sigma_{3}\right)$. On the Nile Delta, the maximum horizontal stress $\left(\mathrm{S}_{\mathrm{Hmax}}\right)$ pattern shows scattered orientations, while on the Aswan region, it has a WNW-ESE strike with pure strike-slip features. The strain-rate field shows the largest values along the Red Sea and the Sinai/Arabia plate boundary. Crustal stretching (up to 40 nanostrain/yr) occurs on these areas with WSW-ENE and NE-SW orientations, while crustal contraction occurs on northern Nile Delta (10 nanostrain/yr) and offshore ( $~ 35$ nanostrain/yr) with E-W and N-S orientations, respectively. The comparison between stress and strain orientations over the investigated area reveals that both patterns are near-parallel and driven by the same large-scale tectonic processes.
\end{abstract}

Keywords: GNSS; earthquake fault-plane solutions; strain; stress; Dead Sea fault system; Red Sea rift; Egypt

\section{Introduction}

Egypt is part of the north-eastern sector of the African continent (Figure 1), where different tectonic plates interact by a complex tectonic evolution since Late Cretaceous [1]. It is surrounded by three plate boundaries where convergent (Hellenic and Cyprian Arc systems), divergent (Gulf of Suez-Red Sea) and transform faulting (Gulf of Aqaba- Dead Sea fault system) processes are currently occurring [2]. Egypt is characterized by earthquakes of low to moderate magnitudes $[3,4]$ which mainly concentrate along the surrounding plate boundaries (Figure 2).

In the last decades, several geodetic and seismological investigations have been carried out, so that the main tectonic features of the region are well known. Assessment on largescale geodetic velocity and strain-rate fields, as well as on the estimation of relative motion between the Nubian, Sinai and the Arabian plates, has been performed in several recent 
studies [2,5-7]. While there is a consensus on the relative motion (in terms of rates and direction) between the Nubia and the Anatolian and Arabian plates, the role of the Sinai sub-plate is largely debated. For instance, no significant differential motion between Sinai and Nubia was detected by [6], while a relative motion of about $2-3 \mathrm{~mm} / \mathrm{yr}$ was inferred by [7] for the northern part of the Sinai Peninsula. Moreover, large discrepancies arise also from the estimated horizontal strain-rate fields, especially regarding the orientation of strain-rate axes. In particular, considering the largest strain-rate axis $\left(\varepsilon_{\mathrm{Hmax}}\right)$, orientations ranging from ENE-WSW to NE-SW were inferred by $[5,7]$ for the northern Red Sea-Gulf of Aqaba region, while orientations ranging from NNW-SSE to NW-SE were inferred by [6] for the same region. Despite the use of different methods in the estimation of strain-rates that can lead to significant variations in results, the large discrepancy reported in the literature appears puzzling, especially if considering that the velocity field reported in [7] includes the one reported in [6].

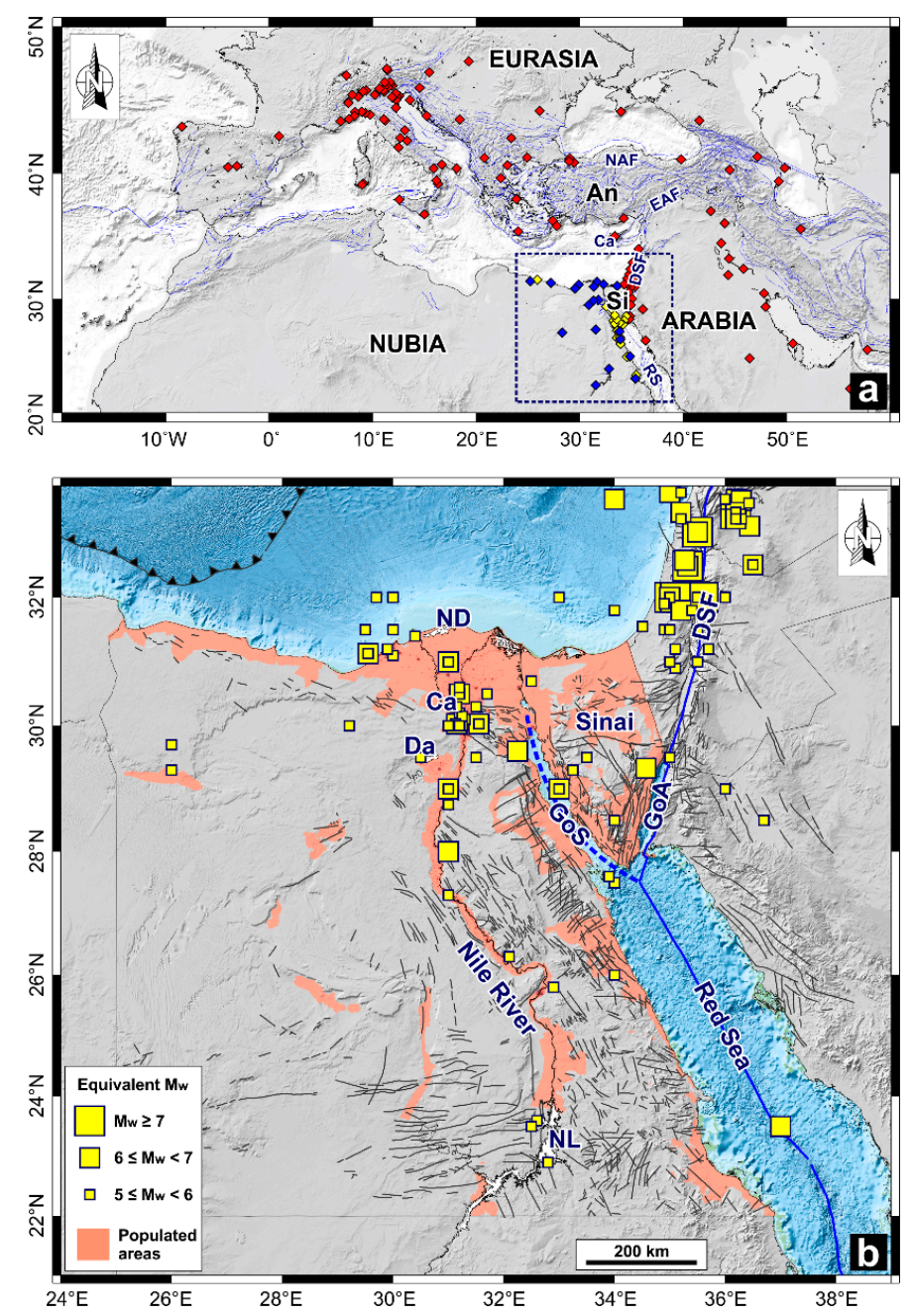

Figure 1. (a) Map of the Mediterranean region showing the main tectonic plates. Active faults are reported as blue lines. The GNSS (Global Navigation Satellite System) stations analyzed in this study are reported as blue (EPGN—Egyptian Permanent GPS Network), red (EUREF [8], SOPAC [9] and UNAVCO [10]) and yellow (survey-type) diamonds. The dashed blue box represents the Scheme 11 (study region). Abbreviations are: $\mathrm{Si}$, Sinai plate; An, Anatolian plate; NAF, North Anatolian fault zone; EAF, East Anatolian fault zone; Ca, Cyprian Arc system; DSF, Dead Sea fault system; RS, Red Sea basin; (b) Simplified tectonic map of Egypt and its surrounding areas. Thin black lines denote major surface faults [11]; thick blue lines stand for plate boundaries [5]. Populated areas [12] and historical seismicity (spanning the 2200 B.C.-1899 A.D. period [13]) are also reported. Abbreviations are: ND, Nile Delta; Ca, Cairo; GoS, Gulf of Suez; GoA, Gulf of Aqaba; Da, Dahshour; NL, Nasser's Lake. 
Very few studies have focused on the crustal stress field of Egypt. Information on the stress field of the investigated area came from the intensive hydrocarbon exploratory drilling carried out in the last six decades $[14,15]$ and earthquake fault plane solutions (FPSs) [15-19]. Achieved results highlighted a spatial variation of the stress field with (i) pure normal faulting mechanism to normal faulting with a secondary strike-slip component on the region comprised between Dahshour, western Cairo and the Gulf of Suez [15,17-19], (ii) strike-slip faulting with a secondary normal slip component or normal faulting with a strike-slip component for the Gulf of Aqaba region $[5,15,18,19]$ and (iii) strike-slip faulting for the surrounding Aswan region [15,17,19]. All these studies inferred a sub-horizontal extensional stress with roughly WSW-ENE orientations on both the Gulf of Suez and the Gulf of Aqaba and NNE-SSW orientations on Dahshour and Aswan regions.

To date, no studies comparing the contemporary crustal stress and surface strain-rate azimuthal patterns (and their characterization) over Egypt have been carried out, although such a comparison has provided relevant insights on tectonic forces acting in different tectonic settings worldwide [20-23]. To fill this gap, we firstly provided an improved snapshot of the present-day crustal tectonic stress and strain-rate fields over Egypt by taking into account updated datasets of seismological and geodetic observations. To this aim, we compiled a database of 74 stress indicators from the World Stress Map project [24] and from new stress inversion analysis carried out on an extensive database of FPSs with magnitude $(M) \geq 3$. In addition, we analyzed a set of GNSS (Global Navigation Satellite System) observations with a long time-span coverage coming from continuously operating stations and survey-type measurements collected over Egypt and its surrounding areas in the last decades. The resulting horizontal geodetic velocity field has been used to derive the strain-rate field over the investigated area on a regular $0.5^{\circ} \times 0.5^{\circ}$ grid. We inferred a normal faulting state of stress with a bimodal crustal extension on the Gulf of Suez, in agreement with previous findings. We also found a normal faulting state of stress along the Sinai / Arabia plate boundary, which, however, is characterized by principal stresses $\sigma_{1}$ and $\sigma_{2}$ very close in magnitude $\left(\sigma_{1} \cong \sigma_{2}>\sigma_{3}\right)$, therefore confirming the coexistence of both faulting stress regimes with permutations of $\sigma_{1}$ and $\sigma_{2}$ stress axes that are in agreement with previous seismological observations $[25,26]$. Finally, the comparison between crustal stress and surface strain orientations over the investigated area reveals that both patterns are near-parallel, hence they are driven by the same tectonic forces.

The achieved results as well as the used geodetic and seismological datasets (see the Supplementary Material) allowed us to upgrade the knowledge on the contemporary stress and strain patterns over the study area, therefore providing new insights and updated datasets for the on-going researches on the regional geodynamics.

\section{Background Setting}

\subsection{Geodynamic Setting}

The current tectonic context of Egypt and its surrounding regions is the result of a complex tectonic evolution started in Late Cretaceous with the beginning of the Eurasia-Africa convergent process [1]. At that time, the Arabian and African plates moved coherently as a single plate [27]. Since Late Eocene ( $\sim 35 \mathrm{Ma})$ the distal Arabian continental margin, driven by its negative buoyancy, moved northward and was underthrusted beneath the Eurasian plate, while the onset of the continental crustal thickening started in Late Oligocene ( 25 Ma [28]). Such a northward motion of Arabia led to the seafloor spreading in the Red Sea basin [29,30]. Differential movement between the Arabian and African/Sinai plates started in Early Miocene with the branching of the northern Red Sea basin into the Gulf of Aqaba and the development of the Dead Sea fault system [31]. Since Middle Miocene, the African plate started to split into two tectonic plates (Nubia and Somalia) along the East African Rift divergent plate boundary [32]. The long-lasting northward migration of the Arabian plate with respect to stable Eurasia resulted in the crustal shortening and thickening of eastern Turkey as well as, since Late Miocene, of the westward extrusion of the Anatolian plate along the North and East Anatolian fault zones [33]. 


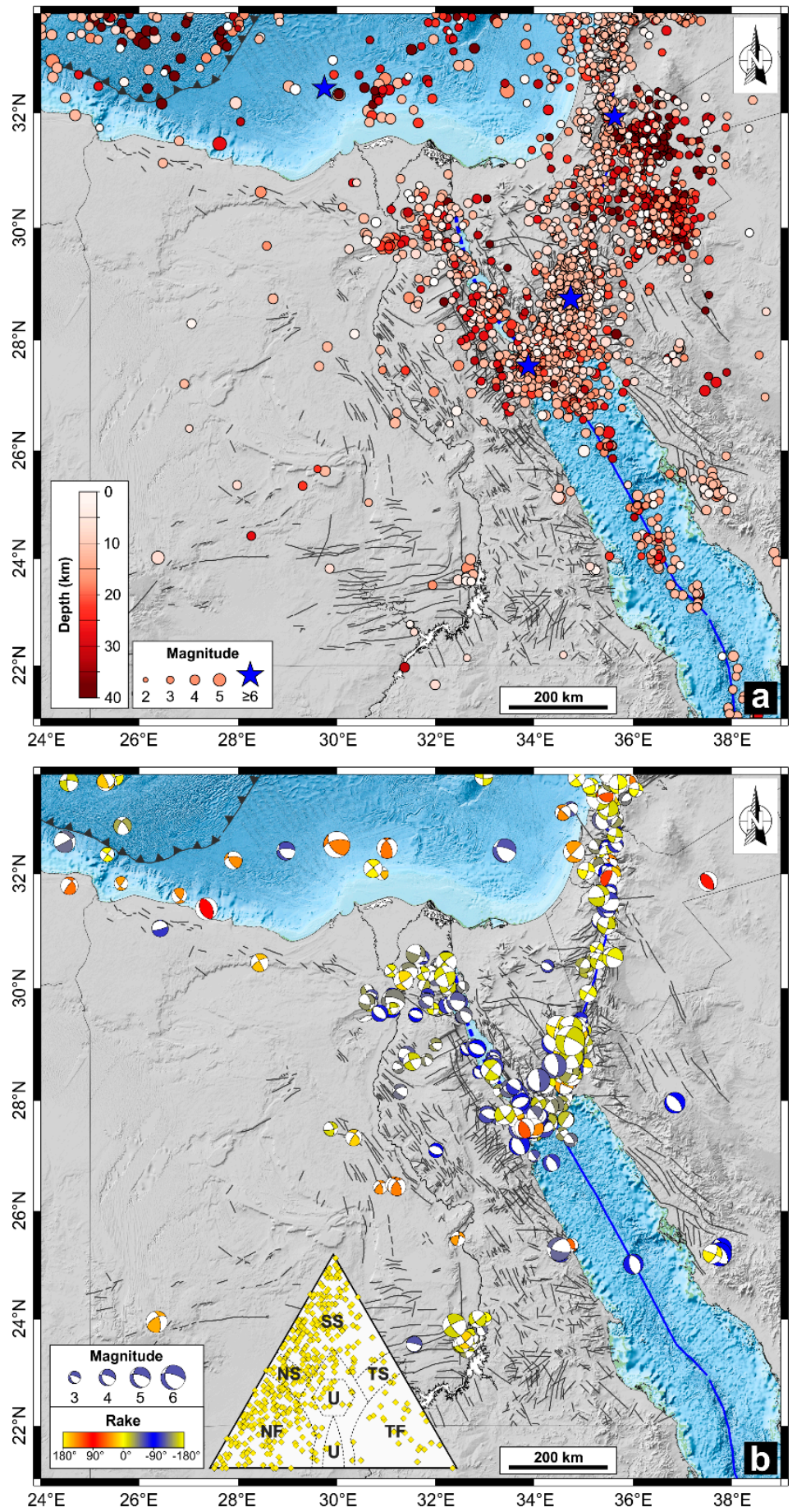

Figure 2. (a) Instrumental crustal seismicity (1927-2020) of Egypt, collected from the International Seismological Center bulletin [34]; (b) lower hemisphere, equal area projection for the 451 fault plane solutions (FPSs) compiled for this study. FPSs are colored according to the value of the rake angle: red, blue and yellow indicate pure thrust faulting, pure normal faulting and strike-slip faulting, respectively. A ternary plot of FPSs is also reported: each point is plotted based on the plunge of the $\mathrm{P}, \mathrm{T}$, and B axes of the FPSs [35]. The dashed lines divide the diagram into faulting styles [14]: NF is normal faulting, NS is normal and with strike-slip component, SS is strike-slip faulting, TS is thrust with strike-slip component, TF is thrust faulting, and U is undefined.

The present-day tectonic arrangement was reached only around $10 \mathrm{Ma}$ ago, when the Nubian plate changed motion to a more NW direction [36] and the Sinai sub-plate became distinct [37] with the formation of the Gulf of Suez. Nowadays, the Nubia plate actively 
converges northward along the Cyprian Arc system with Anatolia and diverges from the Sinai and Arabian plates along the Red Sea basin and the Gulf of Suez (Figure 1a). Motion between the Sinai and Arabian plates occurs along the Gulf of Aqaba and the left-lateral Dead Sea fault system [5].

\subsection{Seismotectonic Setting}

Seismicity, seismotectonics and earthquake hazard in Egypt have been studied by several authors [4,38-42]. Available publications and catalogs of historical earthquakes striking Egypt $[4,38,40,41,43]$ document the occurrence of moderate earthquakes $(M \geq 6)$ in the Egyptian lands at least since 2200 B.C. Historical earthquakes are mainly concentrated along the Nile River and its delta, as well as in the Sinai Peninsula (Figure 1), clearly reflecting the population concentration over the study area. In addition, the Egyptian region was also affected by some large damaging earthquakes nucleated along the Hellenic and the Cyprian Arc systems, as well as those that occurred along the Gulf of Aqaba-Dead Sea fault system [40].

From the International Seismological Centre online catalog [34], we extracted more than 4400 earthquakes (from 1927 to date) having $M \geq 2.0$. The distribution of instrumental seismicity (Figure 2a) highlights that Egypt is characterized by earthquakes of low to moderate magnitudes. Instrumental seismicity is mainly concentrated along the Gulf of Aqaba-Dead Sea fault system and the Gulf of Suez-Red Sea basin and the Nubia-Anatolia plate boundary. Seismicity spreads also on the Cairo-Gulf of Suez area, on the offshore Nile Delta region and the surrounding of Nasser's Lake. Earthquakes with $M \geq 6$ (blue stars in Figure 2a) affecting the study area through the past decades occurred on 11 July 1927 (Ms 6.2), 31 March 1969 (Ms 6.9), 12 September 1955 (Ms 6.2) and 22 November 1995 (Mw 7.2).

\section{Materials and Methods}

In the following, we provide a brief description about data collection, adopted software and methods. In particular, after the collection and characterization of available FPSs (Section 3.1.1), we have performed the stress tensor inversions (Section 3.1.2) on 14 selected subsets, mainly sampling the north-eastern sector of the study area. Regarding the GNSS data (Section 3.2.1) we described how raw observations have been collected, providing a detailed description of their processing, since we adopted two different software packages to overcome the general data policy of the National Research Institute for Astronomy and Geophysics (NRIAG). GNSS velocity and strain-rate estimations are described in Sections 3.2.2 and 3.2.3, respectively.

\subsection{Earthquake Fault Plane Solutions and Stress Tensor Inversions}

\subsubsection{Data Collection}

To study the seismic deformation pattern and draw up a map of stress orientations over the study area, we compiled a database of FPSs by merging data from both public catalogs and the recent literature. The dataset reported in [4], compiled from different catalogs and bulletins [34,44-47] as well as from the literature [25,26,42,48,49], represents our main data source. Additionally, it was updated by including the recent FPSs available from the abovementioned catalogs/bulletins, as well as solutions reported in [5,19]. The final dataset includes 451 FPSs with $\mathrm{Mw} \geq 3.0$ (Figure 2b), which, covering different active seismogenic areas in and around Egypt, cover the 1951-2019 time interval (see Table S1 in Supplementary Material). By adopting a ternary diagram plot [35], FPSs span different faulting styles (Figure 2b), mainly corresponding to strike-slip (34.8\%), normal (31.5\%) and predominantly normal faulting with strike-slip components $(18.6 \%)$. The remaining FPSs correspond to thrust faulting (5.5\%), thrust with strike-slip components (5.3\%) and undefined solutions $(4.3 \%)$. 


\subsubsection{Stress Tensor Inversions}

Based on the natural clustering of available FPSs, we selected 14 subsets (Table 1) which mainly sample the north-eastern sector of the study area (Figure 3).

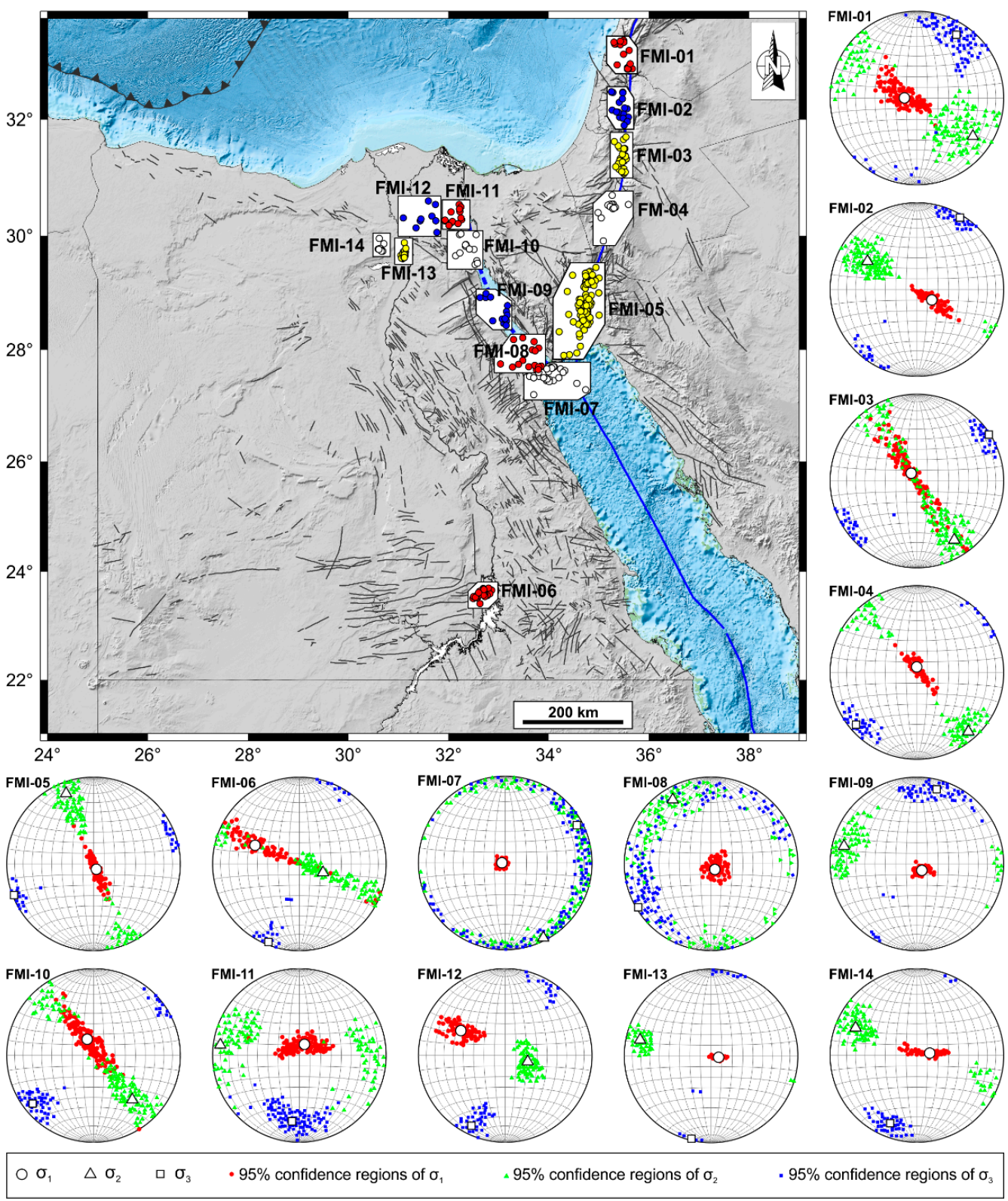

Figure 3. The map shows the 14 subsets selected for the stress tensor inversion. The principal stress axes with their $95 \%$ confidence regions are also plotted on lower hemisphere stereonets (see Table 1 for details).

For each subset, we performed the stress tensor inversion in order to determine the orientations of the principal stress axes, $\sigma_{1}, \sigma_{2}$ and $\sigma_{3}$ (with $\sigma_{1}>\sigma_{2}>\sigma_{3}$ under the compression-positive stress convention) and the value of the stress ratio $R$, defined as:

$$
R=\frac{\left(\sigma_{1}-\sigma_{2}\right)}{\left(\sigma_{1}-\sigma_{3}\right)}
$$

There are several approaches for the stress inversion problem from FPSs. The most commonly used methods have been developed by [50-52] with modifications and extensions proposed by [53-55] and others. Most of these algorithms assume that (i) the 
stress field is homogeneous within the selected space-time domain, (ii) the employed earthquakes are assumed to occur along preexisting faults which have sufficiently different orientations to properly constrain the stress field [56], and (iii) the faults are assumed to slip in the direction of the tangential traction vector [57]. Stress inversions from earthquake fault plane solutions generally require knowledge of which nodal plane is the real fault, however, such information could not be always available.

Table 1. Stress tensor parameters as obtained from the inversion of the FPSs for each selected dataset. Subsets and graphic output of the stress tensor inversions results are reported in Figure 3.

\begin{tabular}{|c|c|c|c|c|c|c|c|c|}
\hline Dataset & $\mathbf{N}$ & $\begin{array}{c}\sigma_{1} \\
\text { az./pl. }\end{array}$ & $\begin{array}{c}\sigma_{2} \\
\text { az./pl. }\end{array}$ & $\begin{array}{c}\sigma_{3} \\
\text { az./pl. }\end{array}$ & $\mathbf{R}$ & $\beta$ & $\begin{array}{c}\text { Stress } \\
\text { Regime }\end{array}$ & $\mathrm{S}_{\text {Hmax }}$ \\
\hline FMI-01 & 17 & $271 / 74$ & $124 / 14$ & $032 / 08$ & 0.43 & 42.4 & NF & 119 \\
\hline FMI-02 & 21 & $126 / 66$ & $300 / 24$ & $031 / 02$ & 0.38 & 29.0 & NF & 122 \\
\hline FMI-03 & 25 & $323 / 77$ & $147 / 13$ & $057 / 01$ & 0.20 & 31.4 & NF & 146 \\
\hline FMI-04 & 13 & $358 / 83$ & $139 / 06$ & $229 / 04$ & 0.38 & 24.6 & NF & 140 \\
\hline FMI-05 & 96 & $152 / 82$ & $339 / 08$ & $249 / 01$ & 0.28 & 41.9 & NF & 159 \\
\hline FMI-06 & 31 & $293 / 32$ & $110 / 58$ & 202/01 & 0.12 & 17.7 & SS & 113 \\
\hline FMI-07 & 38 & $274 / 86$ & $153 / 02$ & $063 / 03$ & 0.93 & 41.9 & NF & 153 \\
\hline FMI-08 & 12 & $146 / 81$ & $329 / 09$ & $239 / 00$ & 0.75 & 35.6 & NF & 149 \\
\hline FMI-09 & 15 & $143 / 79$ & $284 / 09$ & 015/07 & 0.65 & 17.3 & NF & 106 \\
\hline FMI-10 & 16 & $337 / 67$ & $139 / 22$ & $232 / 06$ & 0.20 & 25.9 & NF & 148 \\
\hline FMI-11 & 13 & $024 / 74$ & $278 / 05$ & $187 / 15$ & 0.41 & 32.4 & NF & 95 \\
\hline FMI-12 & 9 & $299 / 29$ & $105 / 60$ & $206 / 06$ & 0.51 & 29.4 & SS & 117 \\
\hline FMI-13 & 23 & $101 / 80$ & $283 / 10$ & $193 / 00$ & 0.46 & 13.1 & NF & 103 \\
\hline FMI-14 & 10 & $079 / 73$ & $294 / 14$ & $202 / 09$ & 0.32 & 14.4 & NF & 107 \\
\hline
\end{tabular}

Here, we used the method developed by [51] since it is suitable for those regions with very small or no information about actual tectonic faults. This method allows one to calculate the confidence regions of the best stress tensor solution by performing a bootstrap resampling technique, in which each nodal plane has the same probability of being selected during the resampling. In this step, we estimated 2000 bootstrap samples to obtain the $95 \%$ confidence region for each of the 14 selected subsets. The average misfit angle $\beta$, i.e., the average angle between the slip direction and the tangential traction on the fault plane, is used as a measure of the success of inversion: if it exceeds $47^{\circ}$ (in the case of the $95 \%$ confidence region), then the inversion has failed to find a uniform-stress tensor, most likely because the true stress field is highly heterogeneous [58]. The achieved results are reported in Figure 3 and Table 1. From the inverted directions of the three principal stresses and the stress ratio, the direction of the maximum horizontal stress $\left(\mathrm{S}_{\mathrm{Hmax}}\right)$ was computed according to [59].

\subsection{Geodetic Observations}

\subsubsection{GNSS Data Collection and Processing}

The monitoring of crustal deformation of the Egyptian territory started in 1994 by the establishment of a network with a few survey sites on the Sinai Peninsula, along the Gulf of Suez and the Greater Cairo region [60]. Successively, other survey sites were established in the Nasser's Lake region [61], southern Sinai [62], Nile Valley [63], the Greater Cairo region [64] and the Abu-Dabbab region [65]. Since 2006, the National Research Institute for Astronomy and Geophysics (NRIAG) established the Egyptian Permanent GPS Network (EPGN) (Figure 1a).

Several GNSS stations tracked only NAVSTAR GPS (NAVigation Satellite Timing and Ranging Global Positioning System) satellites, therefore our processing takes into account only the GPS observations. Raw GPS observations have been firstly processed by using the Bernese [66] and the GAMIT/GLOBK [67] software packages by two independent analysis centers and later combined in GLOBK to estimate a consistent set of station daily coordinates (i.e., time series) and long-term velocity. More in detail, based on the general 
data policy of NRIAG, two different datasets have been defined: a regional and a largescale one (Figure 1a). The former, including all the GNSS stations belonging to EPGN, has been processed at NRIAG by using the Bernese software, while the latter, including 127 continuously operating global tracking GNSS stations, largely from EUREF, SOPAC and UNAVCO facilities (Figure 1a), has been processed at the Istituto Nazionale di Geofisica e Vulcanologia (INGV) by using the GAMIT/GLOBK software.

The processing performed with the Bernese software followed the general guidelines provided by the EUREF Analysis Centers [8], applying a cut-off angle of $10^{\circ}$. To improve the overall configuration of the network and to allow the combination with the dataset processed with the GAMIT/GLOBK software, data coming from 14 common stations were introduced in the processing. The raw observations were processed forming ionospherefree linear combinations and solving for the troposphere biases and phase ambiguities using the quasi ionosphere-free approach. The ocean loading was estimated by using the FES2004 [68] tidal model coefficients as provided by the Ocean Tide Loading provider [69]. The GPS orbits and the Earth's orientation parameters were fixed to the final IGS (International GNSS Service) products and the site coordinates were constrained to an a priori sigma of $10 \mathrm{~m}$, thus the daily coordinates were estimated in a loosely constrained, unknown reference frame and stored as Solution Independent Exchange (SINEX) format files.

During the processing with the GAMIT/GLOBK 10.71 software, the IGS "Repro2 campaign" standards [70] were adopted. In addition to continuous GNSS sites, we included data from 18 survey-type GNSS sites located in eastern and northern Egypt with surveys spanning the 1995-2005 time interval, whose raw observations are available through the UNAVCO archive [10]. To eliminate phase biases related to drifts in the satellite and receiver clock oscillators, an ionosphere-free linear combination of GPS phase observables was adopted during the processing, by applying a double differencing technique. The GPS phase data were weighted according to an elevation-angle-dependent error model, for which a cut-off angle of $10^{\circ}$ was applied, while the IGS absolute antenna phase center models for both satellite and ground-based antennas were adopted. The first-order ionospheric delay was eliminated by using the ionosphere-free linear combination, while a second-order ionospheric corrections [71] was applied by using the IONEX files from the Crustal Dynamics Data Information System [72]. The tropospheric delay was modeled as a piecewise linear model and estimated by using the VMF1 [73]. The Earth orientation parameters were tightly constrained to a priori values obtained from International Earth Rotation Service (IERS) Bulletin B. The ocean tidal loading was corrected using the FES2004 model $[68,69]$. The International Earth Rotation Service (IERS) 2003 model for diurnal and semidiurnal solid Earth tides was also adopted. The results of this processing step are daily estimates of loosely constrained station coordinates, among other parameters, along with the associated variance-covariance matrices.

\subsubsection{GNSS Velocity Estimation}

The daily solutions from both INGV and NRIAG have been combined in a common reference frame with a weighted least squares approach, by using the GLOBK package. During this step, the treatment of Bernese and GAMIT solutions is slightly different because the methods used to generate their initial loosely constrained position estimates are different. The RMS scatters of the position time series at common stations from individual analyses are similar, but the data noise models differ, resulting in the GAMIT position estimates having standard deviations $~ 1.6$ times smaller than the Bernese values. Therefore, we re-scaled the covariance matrices from the two solutions to weigh them equally. Finally, by using the GLORG module of GLOBK, the daily solutions and their full covariance matrices were combined to estimate a consistent set of positions and velocities aligned to the ITRF14 [74] reference frame. To highlight the regional crustal deformation pattern over the investigated area, the ITRF14 velocity field has been rotated into a Nubia reference frame [75] (see Table S2 in Supplementary Material). This last velocity field estimation is shown in Figure 4. 


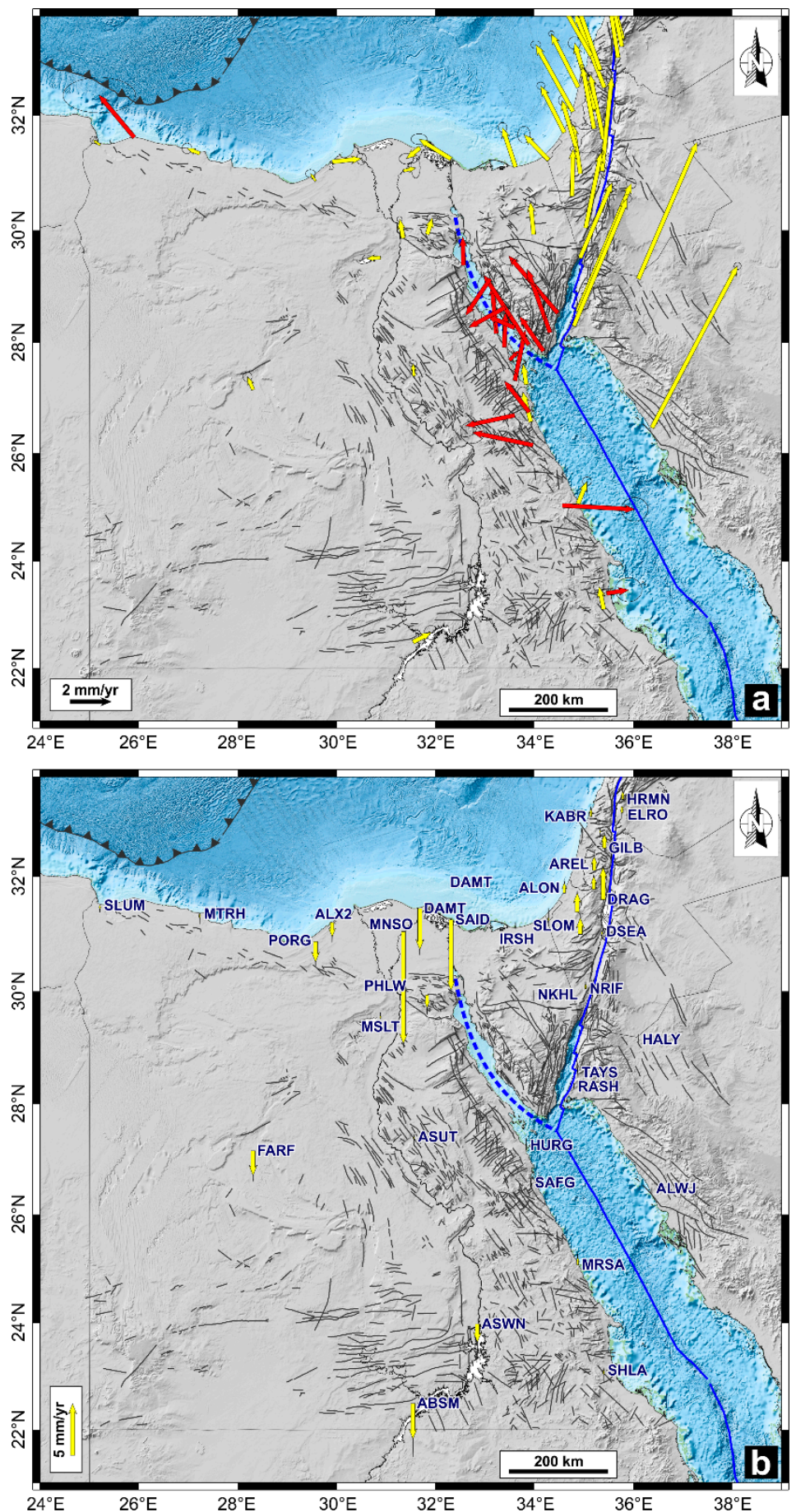

Figure 4. (a) Horizontal GNSS velocities and 95\% confidence ellipses in a fixed Eurasian plate (see Table S2 for details). Continuous and episodic GNSS stations are reported as yellow and red arrows, respectively; (b) vertical GNSS velocities and 95\% confidence uncertainties.

\subsubsection{GNSS Strain-Rate Computation}

By taking into account the estimated velocity field and by adopting the method described in [76], the horizontal strain-rates over the investigated area have been estimated on a regular $0.5^{\circ} \times 0.5^{\circ}$ grid. This method allows one to introduce different spatial weighting functions of data (e.g., uniform Gaussian or quadratic spatial weighting function), enabling one to obtain a finer resolution, especially on regions characterized by sparsely distributed data. After some preliminary tests, the final horizontal strain-rate field has been estimated by using Gaussian and Voronoi cell weighting functions with a weighting 
threshold set to a value of 18 [76]. The estimated horizontal strain-rates and the areal change rates are reported in Figure 5.

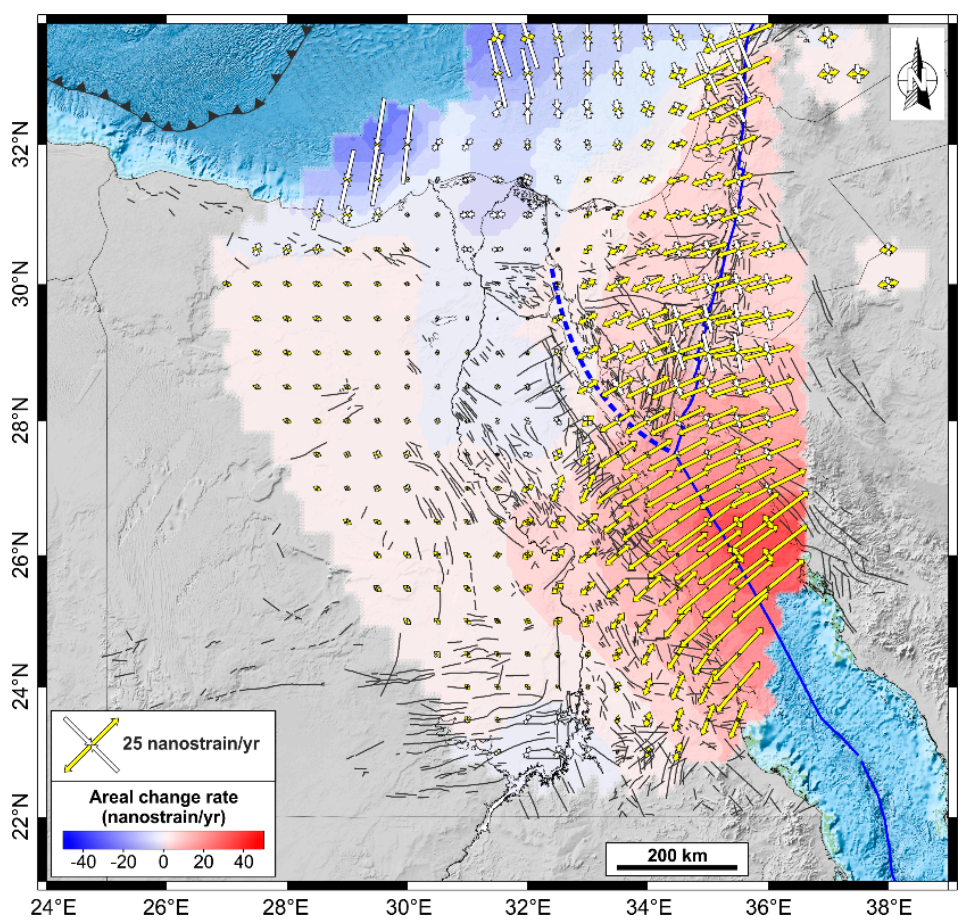

Figure 5. Geodetic strain-rate parameters: colors range in the background shows the magnitude of the areal change rate, while arrows represent $\varepsilon_{\text {Hmax }}$ (yellow) and $\varepsilon_{\text {hmin }}$ (white) horizontal strain-rate axes.

\section{Results and Discussion}

\subsection{Crustal Stress Field}

Our compiled FPSs catalog consists of 451 solutions which mainly concentrated on the north-eastern sector of Egypt. The visual inspection of FPS distribution over the study area (Figure $2 b$ ) indicates that seismic release is predominantly dominated by strike-slip and normal faulting mechanisms, while a few reverse FPSs are located in central-southern Egypt as well as along its northern offshore. The stress tensor inversion allowed us to retrieve the principal stress directions and $\mathrm{R}$ values for the previously defined 14 subsets (Table 1 and Figure 3). As mentioned above, the quality of achieved results can be evaluated based on the retrieved values for the average misfit angle $\beta$ [58]. The values of the misfit angle indicate that the inversions for all the 14 subsets are likely to have successfully identified the homogeneous part of the stress tensor, but for subsets FMI-01, FMI-05 and FMI- 07 , the $\beta$ values are close to the high end of the acceptable misfit range $\left(47^{\circ}\right)$, therefore indicating some heterogeneities in the retrieved stress field.

The two most remarkable features of the achieved results are (1) a $\sigma_{3}$ showing always sub-horizontal orientations, and (2) a large variability of the $\mathrm{R}$ values. Both points reflect the large amount of FPSs with strike-slip, normal and oblique normal faulting reported in our database. Looking at subsets FMI-03, FMI-05, FMI-06 and FMI-10, the 95\% confidence regions of $\sigma_{1}$ and $\sigma_{2}$ form a belt, with trends ranging from NNW-SSE to NW-SE directions (Figure 3$)$. Such a feature, coupled with the low $R$ values (0.12-0.28; Table 1$)$, indicates that, in these subsets, the principal stresses $\sigma_{1}$ and $\sigma_{2}$ are differing slightly only in magnitude $\left(\sigma_{1} \cong \sigma_{2}>\sigma_{3}\right)$, therefore suggesting the coexistence of both faulting stress regimes, with possible permutations of $\sigma_{1}$ and $\sigma_{2}$ stress axes. Regarding subsets FMI-07 and FMI-08, the $95 \%$ confidence regions of $\sigma_{2}$ and $\sigma_{3}$ forms a horizontal belt; this feature, coupled with the high $R$ values (0.75-0.93; Table 1$)$ indicates that for both subsets, the principal stresses $\sigma_{2}$ and $\sigma_{3}$ are closer in magnitude $\left(\sigma_{1}>\sigma_{2} \cong \sigma_{3}\right)$, therefore evidencing a nearly biaxial stress 
state with crust stretching horizontally. The other subsets are characterized by principal stresses with well-defined $95 \%$ confidence regions and $R$ values within the $0.32-0.65$ range.

Taking into account stress results achieved in this study (Table 1), and 60 multidisciplinary indicators for maximum horizontal stress $\left(\mathrm{S}_{\mathrm{Hmax}}\right)$ orientation from the World Stress Map project (see Table S3 of the Supplementary Material for details) we provided an updated view of the present-day, regional stress field of Egypt (Figure 6). Our database is prevalently composed of records coming from wells drilled for hydrocarbon prospection (borehole breakouts and drilling-induced fractures, 52.7\%), FPSs stress inversions (37.8\%) and fault slip data $(9.5 \%)$ for a total of $74 \mathrm{~S}_{\mathrm{Hmax}}$ indicators. The stress indicators coming from FPSs stress inversions densely cover the whole north-eastern sector of Egypt (sampling the crust at a depth of $10 \mathrm{~km}$, on average), while the ones coming from borehole breakout and drilling-induced fractures records (sampling the 0-3.6 km depth interval) are clustered on the on- and offshore of the Nile Delta and along the southern segment of the Gulf of Suez (Figure 5). The few fault slip data, sampling tectonic activity that occurred during the Quaternary, are concentrated along the Dead Sea fault system.

Along this fault system, close to the Sea of Galilee region (Figure 6), the stress field coming from FPSs stress inversions shows a prevailing WNW-ESE orientation, slightly differing from the NNW-SSE strike inferred from surface fault slip data. Such an azimuthal difference could reflect both a dependence of the stress field with respect to the depth and/or a change of the local stress field during the Quaternary. Southward, the stress field orientation shows a progressive clockwise rotation toward a NW-SE attitude along the Gulf of Aqaba. Overall, along this portion of the Sinai/Arabia plate boundary the stress field shows both normal and strike-slip faulting features with generally low $\mathrm{R}$ values (as indicated by the FPSs stress results) and therefore highlighting the coexistence of both faulting stress regimes in agreement with previous stress inversions $[5,18,19]$ and with the extensional pattern of the geodetic strain-rates computed in this study (Figure 5). [25] pointed out that motion along the Dead Sea fault system primarily occurs under a primary left-lateral strike-slip faulting regime while the normal faulting regime reflects the extensional component of the fault system. Moreover, [77] demonstrated that along the southern portion of the Dead Sea fault system, the oblique motion at depth tends to splay near the surface due to the propagation of lobes of strain concentration and their interaction with the free surface, encouraging both the partitioning to dip-slip and strike-slip faulting and the rotation in space and time of the principal axes of the stress field. Therefore, the abundance of both strike-slip and dip-slip FPSs along this fault system, as well as some local different stress orientations (as those observed close to the Sea of Galilee region), can be easily framed in such a simple mechanism.

On the region comprised between the Gulf of Suez and the Nile (Figure 6), the stress field shows a fan-shaped azimuthal pattern, progressively rotating westward from NW-SE to WNW-ESE orientations. The stress field shows a prevailing normal faulting regime, however, on the southern sector of the Gulf of Suez, the high R-values $\left(\sigma_{1}>\sigma_{2} \cong \sigma_{3}\right)$ suggest a nearly biaxial stress state with crustal extension occurring along both the NW-SE and the NE-SW directions. Such a feature matches well with previous findings [15,17-19] and geological data which allow one to recognize the two distinct structural and kinematic fault arrays $[11,78,79]$. On Nile Delta off- and onshore areas, as mentioned previously, the stress orientations, coming from borehole breakouts and drilling-induced fractures records, show a complex pattern. More in detail, on the onshore area of the Nile Delta, the stress field orientation is coherent with the one observed in the Cairo and the Dahshour regions. On the offshore Nile Delta, the western sector is characterized by $\mathrm{S}_{\mathrm{Hmax}}$ indicators with an NNE-SSW attitude, while the eastern sector shows a complex pattern with $S_{\text {Hmax }}$ indicators, showing scattered orientations which could reflect local heterogeneous stress fields within the shallow crust. 


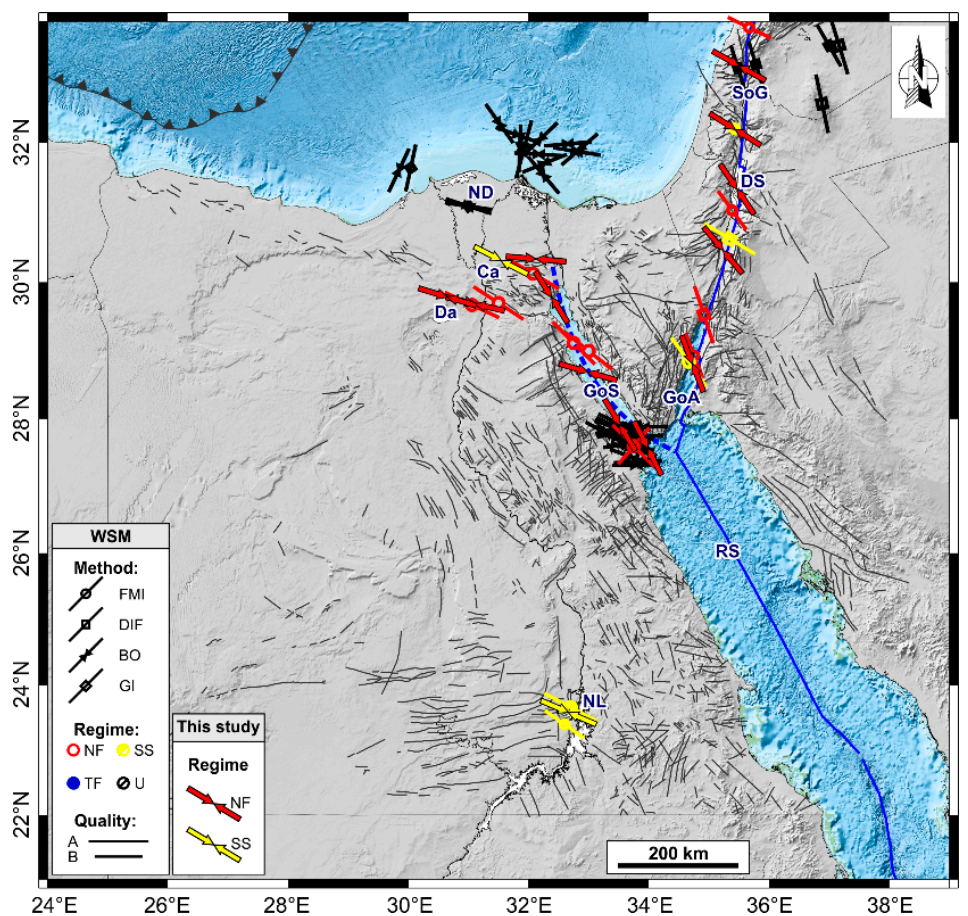

Figure 6. Map of the present-day stress field (in terms of $\mathrm{S}_{\mathrm{Hmax}}$ orientation) inferred from FPSs inversions (FMI), drilling-induced fractures (DIF), borehole breakouts (BO) and geological indicators (GI). NF, normal faulting; SS, strike-slip faulting; TF; thrust faulting; $\mathrm{U}$, undefined. " $\mathrm{A}$ " and " $\mathrm{B}$ " are quality ranking as defined in [80]. Results achieved in this study are reported as large arrows and colored according to the inferred stress regime (Table 1). Abbreviations are: ND, Nile Delta; Ca, Cairo; Da, Dahshour; NL, Nasser's Lake; SoG, Sea of Galilee; DS, Dead Sea; GoA, Gulf of Aqaba; GoS, Gulf of Suez; RS, Red Sea.

On the surroundings of Aswan (Figure 6), all the available $\mathrm{S}_{\mathrm{Hmax}}$ indicators show a coherent WNW-ESE orientation with a strike-slip faulting regime, which is in agreement with previous findings $[15,17,19]$ and the well-known active faults (e.g., the Kalabsha and Seiyal faults) recognized in the area [81].

\subsection{Geodetic Velocities and Strain-Rates Field}

Several studies have focused on the crustal deformation of Egypt [60-65,82,83], providing snapshots of the contemporary deformation over selected regions of the country. A comprehensive analysis of permanent and survey-type GNSS stations available for the Egyptian territory has been firstly reported in [83] and lately partially updated in [7]. Although our study does not have the same station density as these last studies, given the long time-span covered by the analyzed dataset, it provides a crustal velocity field of Egypt with improved precision and smaller uncertainties.

The obtained crustal GNSS velocity field for Egypt, referring to a fixed Nubia reference frame [75], is reported in Figure 4. Regarding the horizontal velocity field (Figure 4a), the episodic stations (red arrows) show an inhomogeneous pattern both in azimuth and magnitude while the continuous ones (black arrows) show a regular pattern. Stations located along the north-western coastal area (SLUM, MTRH and PORG) and central Egypt (FARF, ASUT and ASWN) show residuals smaller than $0.65 \mathrm{~mm} / \mathrm{yr}$, in agreement with the rigid motion of Nubia plate. The continuous stations located along the western side of the Red Sea (HURG SAFG, MRSA and SHLA) show a prevalent northward azimuthal pattern with residuals larger than $1.0 \mathrm{~mm} / \mathrm{yr}$, reflecting the juxtaposition of different forces related to the divergence process between Nubia and Arabia plates. Stations located on the north-eastern Sinai Peninsula show an NNW motion with rates larger than $1.6 \mathrm{~mm} / \mathrm{yr}$, lending credit to the differential motion of the area with respect to the rigid Nubia plate in 
agreement with the findings of other authors $[7,60,62,63,83]$. Regarding the southern sector of the Sinai Peninsula, the crustal motion is defined only by episodic stations, which, as mentioned above, show an inhomogeneous pattern and therefore, no relevant constraints on the independent motion of the Sinai sub-plate can be achieved.

The stations located on the Nile Delta show a complex pattern, both on the horizontal and vertical components. Such a complex pattern reflects the general subsidence of the area in response to different concurrent physical mechanisms as, (a) urban-induced loading, (b) natural sediment compaction and (c) groundwater overexploiting [84,85]. The subsidence rates of the northeastern part of the Nile Delta are larger with respect to the ones observed on the northwestern part as previously observed by $[84,86]$. In particular, the northeastern part of the Nile Delta is characterized by a mean subsidence rate of $\sim 1.6 \mathrm{~mm} / \mathrm{yr}$, while the northwestern part shows mean rates of $\sim 7 \mathrm{~mm} / \mathrm{yr}$; the largest one $(\sim 11 \mathrm{~mm} / \mathrm{yr})$ has been observed at MNSO station (Mansoura city).

Concerning the strain-rate field, the largest values are observed along the eastern sector of Egypt, while the other sectors are characterized by small values $(<5$ nanostrain/yr). In particular, the north-eastern part of the investigated area, encompassing the southern sector of the Dead Sea fault system, is characterized by high strain-rate values (up to $\sim 25$ nanostrain/yr) with $\varepsilon_{\text {hmin }}$ axes prevailing NNW-SSE-oriented, coupled with $\varepsilon_{\mathrm{Hmax}}$ WSW-ENE-oriented, having similar magnitude, therefore highlighting the prevailing strike-slip behavior of the plate boundary. Southward, along the Gulf of Aqaba, the strain field becomes progressively extensional with $\varepsilon_{\mathrm{Hmax}}$ characterized by SW-NE attitudes and values up to $\sim 40$ nanostrain/yr along the Red Sea basin. Along the belt comprised between the Nile River and the Red Sea, the strain field progressively rotates toward an NNE-SSW attitude (coupled also with a significant decrease in strain values). A drastic decrease in strain values is also visible along the Gulf of Suez, with values ranging from $\sim 20$ nanostrain/yr (southward) to $\sim 8$ nanostrain/yr (northward), clearly indicating how the crustal stretching occurs primarily along the Gulf of Aqaba-Dead Sea fault system region. The Cairo-Dahshour region exhibits very small strain-rates (less than 1 nanostrain/yr), while on the northern sector of Nile, the $\varepsilon_{\text {hmin }}$ axes show a E-W orientation with values up to 8 nanostrain/yr, coupled with a negative areal changes of about 10 nanostrain/yr (Figure 6). On the northern offshore area, the strain field shows $\varepsilon_{\text {hmin }}$ axes with a prevailing $\mathrm{N}-\mathrm{S}$ attitude, in response to the ongoing convergence between Nubia and Anatolian plates along the Cyprian Arc system.

\subsection{Stress and Strain-Rate Fields Comparison}

Strain results from the action of stress and a direct geometrical relationship between them there must always be. If strain and stress fields are related to the same process, in the perfectly elastic case, we should observe that both are parallel, while in an anisotropic and inhomogeneous case, they may have an oblique relationship.

Here, to compare the horizontal spatial patterns of stress with strain-rate fields over the investigated area, we estimated a mean orientation of $\mathrm{S}_{\mathrm{Hmax}}$ by grouping all stress indicators in a close geographic position to each grid node with an $\varepsilon_{\text {hmin }}$ orientation. The azimuthal discrepancy between the stress and strain-rate is illustrated in Figure 7 as rotational wedge plots. Such a comparison reveals a high degree of azimuthal correlation (discrepancy less than $30^{\circ}$ ) throughout a large sector of the investigated area including the Gulf of Aqaba-Dead Sea fault system, the northern sector of the Gulf of Suez and the onshore Nile Delta, therefore indicating that at large scale the crustal stress and the surface strain-rate are nearly parallel (Figure 7). 


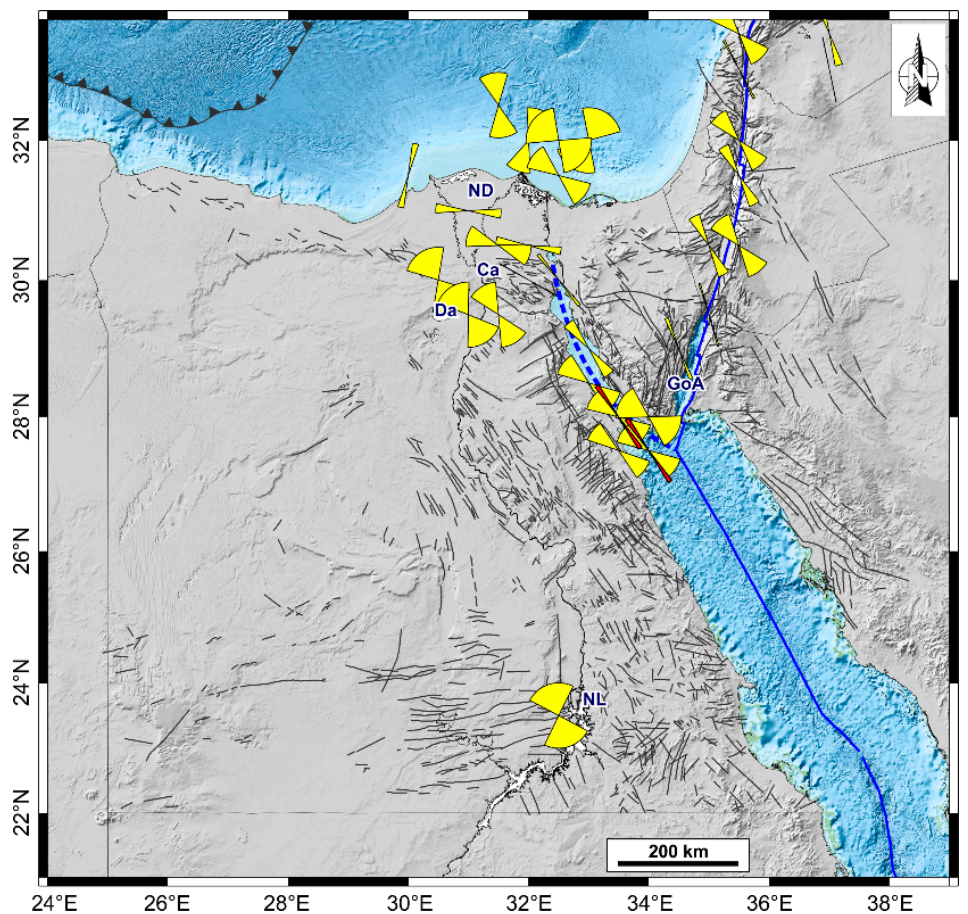

Figure 7. Rotational wedges illustrating the angular difference between the averaged azimuths of the axis of maximum horizontal compressive stress $\left(\mathrm{S}_{\mathrm{Hmax}}\right)$ and the axis of the minimum strain-rate $\varepsilon_{\text {hmin }}$ over the investigated region. The two rotational wedges reported in red, for the southern sector of the Gulf of Suez, show the angular difference between the $\mathrm{S}_{\mathrm{Hmax}}$ estimated by only seismic data (Table 1) and the $\varepsilon_{\text {hmin }}$ axis. Abbreviations are: ND, Nile Delta; Ca, Cairo; Da, Dahshour; NL, Nasser's Lake; GoA, Gulf of Aqaba.

Local intermediate correlations (discrepancy within the $30^{\circ}-60^{\circ}$ interval) are visible along the southern sector of the Gulf of Suez, where much of the stress indicators came from borehole breakouts and drilling-induced fracture records, sampling the shallow crust. Indeed, such an intermediate correlation occurs only averaging all the available stress orientations. Taking into account only the stress indicators coming from FPSs (Table 1 and the red rotational wedges reported in Figure 7), a high degree of azimuthal correlation between stress and strain-rate can be observed. Such a feature suggests that in the southern Gulf of Suez, at shallow depth, the stress and strain-rate have an oblique relationship, reflecting the action of local and shallow tectonic sources, while at depth, both are near-parallel, and they are mainly related to large scale tectonic processes. On the Cairo-Dahshour region and the Nile Delta offshore, both intermediate and low correlations (discrepancy exceeding $60^{\circ}$; Figure 7) can be recognized. While in the Nile Delta offshore, the observed low correlation would reflect the scattered orientation of the stress indicators, on the Cairo-Dahshour region, it could be related to not well constrained orientations of strain axes because of their very small values and the poor distribution of GNSS sites in the region. A similar consideration could be suggested for the Aswan region (Figure 7).

\section{Conclusions}

We investigated the present-day stress and strain-rate fields of Egypt through the analyses of earthquake fault plane solutions and GNSS data, providing new insights and updated datasets for on-going and future researches on the regional geodynamics. Our main findings are summarized below.

The stress field shows a general fan-shaped azimuthal pattern with orientation rotating from WNW-ESE (westward of the Gulf of Suez) to NNW-SSE (along the Gulf of AqabaDead Sea fault system). Scattered orientations, coming from shallow borehole breakouts and drilling-induced fracture records, can be observed on the offshore Nile Delta and the 
southern Gulf of Suez. Overall, the inferred crustal stress field shows a prevailing normal faulting regime. However, along the Sinai/Arabia plate boundary, the normal faulting regime coexists with a strike-slip one $\left(\sigma_{1} \cong \sigma_{2}>\sigma_{3}\right)$, while on the Gulf of Suez, it is characterized by crustal extension occurring along near-orthogonal directions $\left(\sigma_{1}>\sigma_{2} \cong \sigma_{3}\right)$. Both features are in agreement with both seismological and geological observations.

The GNSS velocity field indicates that Egypt is rigidly connected with the Nubia plate, while the north-eastern sector of the Sinai Peninsula shows a differential motion with respect to Nubia, in agreement with the findings of other authors. The stations located on the Nile Delta show a complex pattern, both on horizontal and vertical components, reflecting the general subsidence of the area in response to different concurrent physical mechanisms (urban-induced loading, natural sediment compaction and groundwater overexploiting). Large strain-rate values (up to $\sim 40$ nanostrain/yr) are observed along the eastern sector of the study area, while the other sectors are characterized by small values ( $<5$ nanostrain/yr). The region is dominated by a general crustal stretching with NE-SW orientations along the Red Sea basin and WSW-ENE along the Gulf of AqabaDead Sea fault system. Crustal contraction occurs on the northern sector of the Nile River ( 10 nanostrain/yr) and offshore ( $\sim 30$ nanostrain/yr).

The comparison between the crustal stress and strain-rate field reveals a high degree of azimuthal correlation throughout much of a large sector of the investigated area, suggesting that both fields reflect the action of large-scale tectonic processes. Moreover, some local discrepancies would reflect the action of shallow stress sources.

In conclusion, the achieved results, especially those related to geodetic measurements, highlight the need to improve the coverage of the current GNSS stations' density over some key sectors of Egypt such as the northern and the eastern ones in order to properly understand both local and regional tectonic processes and to provide appropriate means to mitigate the natural hazards in such densely populated sectors.

Supplementary Materials: The following are available online at https:/ /www.mdpi.com/article/ 10.3390/rs13071398/s1, Table S1: Earthquake fault plane solutions, Table S2: Site coordinates and velocities referred to ITRF14 and fixed Nubia plate. Table S3: $\mathrm{S}_{\mathrm{Hmax}}$ stress indicator inferred from borehole breakouts (BO), inversion of FPSs for stress tensor (FMF), geological indicator (GI) and drilling-induced fractures (DIF). Data have been collected from the World Stress Map Database [31] according to their A and B quality ranking.

Author Contributions: Conceptualization, M.P.; methodology, M.P.; software, M.P., M.R., A.M.R., R.S., F.S. and J.A.P.; validation, M.P., J.A.P.; formal analysis, M.P., M.R., A.M.R., R.S. and J.A.P.; investigation, M.P.; data curation, M.P., M.R., A.M.R., R.S., F.S. and J.A.P.; writing-original draft preparation, M.P.; visualization, M.P., R.S. and F.S.; supervision M.P. All authors have read and agreed to the current version of the manuscript.

Funding: This research was partially funded by the Programa Operativo FEDER Andalucía 20142020-A call made by the University of Jaén 2018.

Data Availability Statement: Data are reported in the Supplementary Material section in the form of tables.

Acknowledgments: Authors are grateful to the staff members of both the Egyptian National Seismic Network (Seismology Department) and the Crustal Movement Laboratory (Geodynamics Department) of the National Research Institute of Astronomy and Geophysics (NRIAG), Cairo, Egypt, for providing access to local seismic data and helping with GNSS data acquisition. Episodic GNSS observations used in this paper have been provided by UNAVCO, Inc., with support from the National Science Foundation (NSF) and the National Aeronautics and Space Administration (NASA) under NSF Cooperative Agreement EAR-1724794.

Conflicts of Interest: The authors declare no conflict of interest. 


\section{References}

1. Moores, E.M.; Fairbridge, R.W. Encyclopedia of European and Asian Regional Geology; Encyclopedia of Earth Sciences Series; Springer: London, UK, 1998.

2. Reilinger, R.; McClusky, S. Nubia-Arabia-Eurasia plate motions and the dynamics of Mediterranean and Middle East tectonics. Geophys. J. Int. 2011, 186, 971-979. [CrossRef]

3. Sawires, R.; Peláez, J.A.; Fat-Helbary, R.E.; Panzera, F.; Ibrahim, H.A.; Hamdache, M. Probabilistic seismic hazard deaggregation for selected Egyptian cities. Pure Appl. Geophys. 2017, 174, 1581-1600. [CrossRef]

4. Sawires, R.; Peláez, J.A.; Fat-Helbary, R.E.; Ibrahim, H.A. An Earthquake Catalogue (2200 B.C. to 2013) for Seismotectonic and Seismic Hazard Assessment Studies in Egypt. In Earthquakes and Their Impact on Society; D'Amico, S., Ed.; Springer Natural Hazards, Springer: Cham, Switzerland, 2016.

5. Palano, M.; Imprescia, P.; Gresta, S. Current stress and strain-rate fields across the Dead Sea Fault System: Constraints from seismological data and GPS observations. Earth Planet. Sci. Lett. 2013, 369-370, 305-316. [CrossRef]

6. Saleh, M.; Becker, M. New constraints on the Nubia-Sinai-Dead Sea fault crustal motion. Tectonophysics 2015, 651, 79-98. [CrossRef]

7. Pietrantonio, G.; Devoti, R.; Mahmoud, S.; Riguzzi, F. Kinematics of the Suez-Sinai area from combined GPS velocity field. J. Geodyn. 2016, 102, 231-238. [CrossRef]

8. EUREF. Permanent GNSS Network. Available online: www.epncb.oma.be (accessed on 23 February 2021).

9. SOPAC. Scripps Orbit and Permanent Array Center. Available online: http:/ / sopac-csrc.ucsd.edu (accessed on 15 March 2021).

10. UNAVCO. Available online: www.unavco.org (accessed on 23 February 2021).

11. Egyptian Geological Survey Authority. Geological Map of Egypt; Egyptian Geological Survey Authority: Cairo, Egypt, 1981.

12. World Pop Open Spatial Demographic Data and Research. Available online: www.worldpop.org (accessed on 23 February 2021).

13. Sawires, R.F.; Peláez, J.; Fat-Helbary, R.; Ibrahim, H.; Hernández, H.I.A.M.G. An updated seismic source model for Egypt. In Earthquake Engineering —From Engineering Seismology to Optimal Seismic Design of Engineering Structures; IntechOpen: London, UK, 2015; pp. 1-52. [CrossRef]

14. Zoback, M.L. First-and second-order patterns of stress in the lithosphere: The World Stress Map Project. J. Geophys. Res. Solid Earth 1992, 97, 11703-11728. [CrossRef]

15. Badawy, A. Status of the crustal stress in Egypt as inferred from earthquake focal mechanisms and borehole breakouts. Tectonophysics 2001, 343, 49-61. [CrossRef]

16. Badawy, A. Seismicity of Egypt. Seism. Res. Lett. 2005, 76, 149-160. [CrossRef]

17. Hussein, H.M.; Elenean, K.A.; Marzouk, I.; Korrat, I.M.; Abu El-Nader, I.; Ghazala, H.; ElGabry, M. Present-day tectonic stress regime in Egypt and surrounding area based on inversion of earthquake focal mechanisms. J. Afr. Earth Sci. 2013, 81, 1-15. [CrossRef]

18. Mohamed, E.K.; Hassoup, A.; Elenean, K.A.; Othman, A.A.; Hamed, D.-E.M. Earthquakes focal mechanism and stress field pattern in the northeastern part of Egypt. NRIAG J. Astron. Geophys. 2015, 4, 205-221. [CrossRef]

19. Ali, S.M.; Badreldin, H. Present-day stress field in Egypt based on a comprehensive and updated earthquake focal mech-anisms catalog. Pure Appl. Geophys. 2019, 176, 4729-4760. [CrossRef]

20. Chang, C.-P.; Chang, T.-Y.; Angelier, J.; Kao, H.; Lee, J.-C.; Yu, S.-B. Strain and stress field in Taiwan oblique convergent system: Constraints from GPS observation and tectonic data. Earth Planet. Sci. Lett. 2003, 214, 115-127. [CrossRef]

21. Townend, J.; Zoback, M.D. Stress, strain, and mountain building in central Japan. J. Geophys. Res. Space Phys. 2006, 111. [CrossRef]

22. Keiding, M.; Lund, B.; Árnadóttir, T. Earthquakes, stress, and strain along an obliquely divergent plate boundary: Reykjanes Peninsula, southwest Iceland. J. Geophys. Res. Space Phys. 2009, 114, 09306. [CrossRef]

23. Palano, M.; González, P.J.; Fernández, J. The Diffuse Plate boundary of Nubia and Iberia in the Western Mediterranean: Crustal deformation evidence for viscous coupling and fragmented lithosphere. Earth Planet. Sci. Lett. 2015, 430, 439-447. [CrossRef]

24. The World Stress Map Project-A Service for Science and Earth System Management. Available online: www.world-stress-map. org/ (accessed on 23 February 2021).

25. Salamon, A.; Hofstetter, A.; Garfunkel, Z.; Ron, H. Seismotectonics of the Sinai subplate-The eastern Mediterranean region. Geophys. J. Int. 2003, 155, 149-173. [CrossRef]

26. Hofstetter, A. Seismic observations of the 22/11/1995 Gulf of Aqaba earthquake sequence. Tectonophysics 2003, 369, 21-36. [CrossRef]

27. Jolivet, L.; Faccenna, C. Mediterranean extension and the Africa-Eurasia collision. Tectonics 2000, 19, 1095-1106. [CrossRef]

28. Mouthereau, F.; Lacombe, O.; Vergés, J. Building the Zagros collisional orogen: Timing, strain distribution and the dynamics of Arabia/Eurasia plate convergence. Tectonophysics 2012, 532-535, 27-60. [CrossRef]

29. Brew, G.; Lupa, J.; Barazangi, M.; Sawaf, T.; Al-Imam, A.; Zaza, T. Structure and tectonic development of the Ghab basin and the Dead Sea fault system, Syria. J. Geol. Soc. 2001, 158, 665-674. [CrossRef]

30. Montadert, L.; Nicolaides, S.; Semb, P.H.; Lie, Ø.; Marlow, L.; Kendall, C.C.; Rose, L.A. Petroleum Systems Offshore Cyprus. In Petroleum Systems of the Tethyan Region; Marlow, L., Kendall, C., Yose, L., Eds.; American Association of Petroleum Geologists: Washington, DC, USA, 2014; pp. 301-334.

31. Bartov, Y.; Steinitz, G.; Eyal, M.; Eyal, Y. Sinistral movement along the Gulf of Aqaba-Its age and relation to the opening of the Red Sea. Nature 1980, 285, 220-222. [CrossRef] 
32. Macgregor, D. History of the development of the East African Rift System: A series of interpreted maps through time. J. Afr. Earth Sci. 2015, 101, 232-252. [CrossRef]

33. Bulut, F.; Bohnhoff, M.; Eken, T.; Janssen, C.; Kılıç, T.; Dresen, G. The East Anatolian Fault Zone: Seismotectonic setting and spatiotemporal characteristics of seismicity based on precise earthquake locations. J. Geophys. Res. Space Phys. $2012,117$. [CrossRef]

34. International Seismological Centre. Available online: www.isc.ac.uk/iscbulletin/search/catalogue/ (accessed on 23 February 2021).

35. Frohlich, C. Triangle diagrams: Ternary graphs to display similarity and diversity of earthquake focal mechanisms. Phys. Earth Planet. Inter. 1992, 75, 193-198. [CrossRef]

36. Dewey, J.F.; Helman, M.L.; Knott, S.D.; Turco, E.; Hutton, D.H.W. Kinematics of the western Mediterranean. Geol. Soc. Lond. Spéc. Publ. 1989, 45, 265-283. [CrossRef]

37. Joffe, S.; Garfunkel, Z. Plate kinematics of the circum Red Sea-A re-evaluation. Tectonophysics 1987, 141, 5-22. [CrossRef]

38. Maamoun, M.; Megahed, A.; Allam, A. Seismicity of Egypt. Helwan Obs. Bull. 1984, 4, 109-160.

39. Kebeasy, R.M. Seismicity. In The Geology of Egypt; Said, R., Ed.; A.A. Balkema: Rotterdam, The Netherlands, 1990; pp. 51-59.

40. Ambraseys, N.N.; Melville, C.P.; Adams, R.D. The Seismicity of Egypt, Arabia and the Red Sea; Cambridge University Press: Cambridge, UK, 1994; pp. 1-137.

41. Badawy, A. Historical seismicity of Egypt. Acta Geod. Geophys. Hung. 1999, 34, 119-135.

42. Abou Elenean, K.M. Focal mechanisms of small and moderate size earthquakes recorded by the Egyptian National Seismic Network (ENSN), Egypt. NRIAG J. Geophys. 2007, 6, 119-153.

43. Poirier, J.P.; Taher, M.A. Historical seismicity in the near and Middle East, North Africa, and Spain from Arabic documents (VIIth-XVIIIth century). Bull. Seismol. Soc. Am. 1980, 70, 2185-2201.

44. Global CMT Web Page. Available online: www.globalcmt.org (accessed on 23 February 2021).

45. European-Mediterranean RCMT Catalog-European-Mediterranean Regional Centroid-Moment Tensors. Available online: rcmt2.bo.ingv.it (accessed on 23 February 2021).

46. ENSN-Athena. Available online: http:/ / ensn.nriag.sci.eg/ (accessed on 23 February 2021).

47. NEIC-USGS-Earthquake Hazards Program. Available online: earthquake.usgs.gov/earthquakes/search/ (accessed on 23 February 2021).

48. Korrat, I.; El Agami, N.; Hussein, H.; El-Gabry, M. Seismotectonics of the passive continental margin of Egypt. J. Afr. Earth Sci. 2005, 41, 145-150. [CrossRef]

49. Badawy, A.A.; Al-Werr, A.; Ali, S.M. Relative location and source mechanism of inland earthquakes in Northern Egypt. J. Seism. 2013, 18, 257-276. [CrossRef]

50. Michael, A.J. Determination of stress from slip data: Faults and folds. J. Geophys. Res. Space Phys. 1984, 89, 11517-11526. [CrossRef]

51. Michael, A.J. Use of focal mechanisms to determine stress: A control study. J. Geophys. Res. Space Phys. 1987, 92, 357-368. [CrossRef]

52. Gephart, J.W.; Forsyth, D.W. An improved method for determining the regional stress tensor using earthquake focal mechanism data: Application to the San Fernando Earthquake Sequence. J. Geophys. Res. Space Phys. 1984, 89, 9305-9320. [CrossRef]

53. Lund, B.; Slunga, R. Stress tensor inversion using detailed microearthquake information and stability constraints: Appli-cation to Ölfus in southwest Iceland. J. Geophys. Res. Solid Earth 1999, 104, 14947-14964. [CrossRef]

54. Arnold, R.; Townend, J. A Bayesian approach to estimating tectonic stress from seismological data. Geophys. J. Int. 2007, 170, 1336-1356. [CrossRef]

55. Vavryčuk, V. Iterative joint inversion for stress and fault orientations from focal mechanisms. Geophys. J. Int. 2014, 199, 69-77. [CrossRef]

56. McKenzie, D.P. The relation between fault plane solutions for earthquakes and the directions of the principal stresses. Bull. Seismol. Soc. Am. 1969, 59, 591-601.

57. Bott, M.H.P. The Mechanics of Oblique Slip Faulting. Geol. Mag. 1959, 96, 109-117. [CrossRef]

58. Michael, A.J. Spatial variations in stress within the 1987 Whittier Narrows, California, aftershock sequence: New techniques and results. J. Geophys. Res. Space Phys. 1991, 96, 6303-6319. [CrossRef]

59. Lund, B.; Townend, J. Calculating horizontal stress orientations with full or partial knowledge of the tectonic stress tensor. Geophys. J. Int. 2007, 170, 1328-1335. [CrossRef]

60. Mahmoud, S.; Reilinger, R.; McClusky, S.; Vernant, P.; Tealeb, A. GPS evidence for northward motion of the Sinai Block: Implications for E. Mediterranean tectonics. Earth Planet. Sci. Lett. 2005, 238, 217-224. [CrossRef]

61. Radwan, A.M.; Hosny, A.; Kotb, A.; Khalil, A.; Abed, A.; Fernandes, R.M.S.; Rayan, A. Assessment of the geodynamical settings around the main active faults at Aswan area, Egypt. Arab. J. Geosci. 2014, 8, 4317-4327. [CrossRef]

62. Riguzzi, F.; Mahmoud, S.M.; Tealeb, A. Displacement pattern of the Sinai area: First results from GPS. Ann. Geophys. 1999, 42. [CrossRef]

63. Sakr, K.; Radwan, A.M.; Rashwan, M.; Gomaa, M. Estimation of crustal movements using the Global Positioning System (GPS) measurements along Nile Valley area, Egypt from 2007 to 2012. NRIAG J. Astron. Geophys. 2015, 4, 55-63. [CrossRef]

64. Abdel-Monem, S.M.; Zahran, K.H.; Saleh, M.; Yossef, M.M.; Omran, A.A.; Radwan, A.M. Gavity observation and crustal deformation at Cairo Region and its geodynamical implications. World Appl. Sci. J. 2013, 21, 1721-1728. 
65. Abdel-Monem, S.M.; Becker, M.; Saleh, M. Comparative deformation analysis for Abu Dabab area, Egypt. Acta Geod. Geophys. Hung. 2012, 47, 1-18.

66. Dach, R.; Lutz, S.; Walser, P.; Fridez, P. Bernese GNSS Sofware Version 5.2; Astronomical Institute, University of Bern: Bern, Switzerland, 2015. Available online: http:/ / www.bernese.unibe.ch/docs/DOCU52.pdf (accessed on 23 February 2021).

67. Herring, T.A.; King, R.W.; Floyd, M.A.; McClusky, S.C. Introduction to GAMIT/GLOBK, Release 10.7; Massachusetts Institute of Technology: Cambridge, UK, 2018. Available online: www-gpsg.mit.edu (accessed on 23 February 2021).

68. Lyard, F.; Lefevre, F.; Letellier, T.; Francis, O. Modelling the global ocean tides: Modern insights from FES2004. Ocean Dyn. 2006, 56, 394-415. [CrossRef]

69. Welcome to the Free Ocean Tide Loading Provider. Available online: holt.oso.chalmers.se/loading (accessed on 23 February 2021).

70. International GNSS Service-2nd Data Reprocessing Campaign. Available online: acc.igs.org/reprocess2.html (accessed on 23 February 2021).

71. Petrie, E.J.; King, M.A.; Moore, P.; Lavallée, D.A. Higher-order ionospheric effects on the GPS reference frame and veloci-ties. J. Geophys. Res. Solid Earth 2010, 115. [CrossRef]

72. NASA Earth Data. Available online: https://cddis.nasa.gov/archive/gnss/products/ionex/ (accessed on 23 February 2021).

73. Boehm, J.; Werl, B.; Schuh, H. Troposphere mapping functions for GPS and very long baseline interferometry from European Centre for Medium-Range Weather Forecasts operational analysis data. J. Geophys. Res. Solid Earth 2006, 111. [CrossRef]

74. Altamimi, Z.; Rebischung, P.; Métivier, L.; Collilieux, X. ITRF2014: A new release of the International Terrestrial Reference Frame modeling nonlinear station motions. J. Geophys. Res. Solid Earth 2016, 121, 6109-6131. [CrossRef]

75. Saria, E.E.; Calais, E.; Stamps, D.S.; Delvaux, D.; Hartnady, C.J.H. Present-day kinematics of the East African Rift. J. Geophys. Res. Solid Earth 2014, 119, 3584-3600. [CrossRef]

76. Shen, Z.; Wang, M.; Zeng, Y.; Wang, F. Optimal Interpolation of Spatially Discretized Geodetic Data. Bull. Seism. Soc. Am. 2015, 105, 2117-2127. [CrossRef]

77. Devès, M.H.; King, G.C.; Klinger, Y.; Agnon, A. Localised and distributed deformation in the lithosphere: Modelling the Dead Sea region in 3 dimensions. Earth Planet. Sci. Lett. 2011, 308, 172-184. [CrossRef]

78. Lyberis, N. Tectonic evolution of the Gulf of Suez and the Gulf of Aqaba. Tectonophysics 1988, 153, 209-220. [CrossRef]

79. Montenat, C.; D'Estevou, P.O.; Jarrige, J.-J.; Richert, J.-P. Rift development in the Gulf of Suez and the north-western Red Sea: Structural aspects and related sedimentary processes. In Sedimentation and Tectonics in Rift Basins Red Sea Gulf of Aden; Springer: Dordrecht, The Netherlands, 1998; pp. 97-116.

80. Heidbach, O.; Barth, A.; Müller, B.; Reinecker, J.; Stephansson, O.; Tingay, M.; Zang, A. WSM Quality Ranking Scheme, Database Description and Analysis Guidelines for Stress Indicator; World Stress Map Technical Report 16-01; GFZ German Research Centre for Geosciences: Potsdam, Germany, 2016.

81. Awad, M.; Mizoue, M. Earthquake activity in the Aswan region, Egypt. Pure Appl. Geophys. 1995, 145, 69-86. [CrossRef]

82. Abou-Aly, N.; Abdel-Monem, S.M.; Salah, M.; Saleh, M.; Sherif, M.; Khalil, H.; Hassib, G.; Rayan, A. Gps Measurements of Current Crustal Movements along the Gulf of Suez. 2011, pp. 45-66. Available online: http://www.unoosa.org/documents/pdf/ psa/activities/2011/UAE/Presentations/33.pdf (accessed on 26 February 2021).

83. Saleh, M.; Becker, M. A new velocity field from the analysis of the Egyptian Permanent GPS Network (EPGN). Arab. J. Geosci. 2013, 7, 4665-4682. [CrossRef]

84. Saleh, M.; Becker, M. New estimation of Nile Delta subsidence rates from InSAR and GPS analysis. Environ. Earth Sci. 2018, 78, 6. [CrossRef]

85. Rateb, A.; Abotalib, A.Z. Inferencing the land subsidence in the Nile Delta using Sentinel-1 satellites and GPS between 2015 and 2019. Sci. Total. Environ. 2020, 729, 138868. [CrossRef] [PubMed]

86. Becker, R.H.; Sultan, M. Land subsidence in the Nile Delta: Inferences from radar interferometry. Holocene 2009, 19, 949-954. [CrossRef] 